\title{
References
}

Acemoglu, D., Johnson, S. and Robinson, J. (2004). Institutions as the Fundamental Cause of Long-run Growth. Retrieved March 2014 from http://www.nber.org/papers/w10481.

Adhikari, K. and Goldey, P. (2010). Social capital and its "downside": The impact on sustainability of induced community-based organizations in Nepal. World Development, 38(2), 184-94.

Aguiar, F., Branas-Garza, P. and Miller, L. (2008). Moral distance in dictator games. Judgment and Decision Making Journal, 3(4), 344-54.

Aked, J., Marks, N., Cordon, C. and Thompson, S. (2008). Five Ways to Wellbeing. Retrieved February 2015 from http://b.3cdn.net/nefounda tion/8984c5089d5c2285ee_t4m6bhqq5.pdf.

Akerlof, G. and Kranton, R. (2000). Economics and identity. Quarterly Journal of Economics, 115(3), 715-53.

Aknin, L., Barrington-Leigh, C., Dunn, E., Helliwell, J., Burns, J., Biswas-Diener, R., Kemeza, I. et al. (2013). Prosocial spending and wellbeing: Cross-cultural evidence for a psychological universal. Journal of Personality and Social Psychology, 104(4), 635-52.

Alesina, A. and La Ferrara, E. (2000). Participation in heterogeneous communities. Quarterly Journal of Economics, 115(3), 847-904.

Algan, Y. and Cahuc, P. (2013). Trust, growth and well-being: New evidence and policy implications. IZA Discussion Paper No. 7464.

Algan, Y., Cahuc, P. and Shleifer, A. (2013). Teaching practices and social capital. American Economic Journal: Applied Economics, 5(3), 189-210.

Anderson, L., Mellor, J. and Milyo, J. (2004). Social capital and contributions in a public-goods experiment. American Economic Review, 94(2), $373-6$.

Andreoni, J. (1995). Warm-glow versus cold-prickle: The effects of positive and negative framing on cooperation in experiments. Quarterly Journal of Economics, 110(1), 1-21.

Andreoni, J. and Scholz, J. (1998). An econometric analysis of charitable giving with interdependent preferences. Economic Inquiry, 36(3), $410-28$.

Andreoni, J., Gale, W. and Scholz, J. (1996). Charitable Contributions 
of Time and Money. Retrieved March 2015 from http://econweb.ucsd. $\mathrm{edu} / \sim$ jandreon/WorkingPapers/ags-v8.pdf.

Ariely, D. (2008). Predictably Irrational: The Hidden Forces that Shape our Decisions. New York: HarperCollins.

Arrondel, L. and Masson, A. (2006). Altruism, exchange or indirect reciprocity: What do the data on family transfers show? In S-C. Kolm and J. Ythier (eds), Handbook on the Economics of Giving, Reciprocity and Altruism. Amsterdam, the Netherlands and London, UK: Elsevier.

Arrow, K., Sen, A. and Suzumura, K. (1997). Social Choice Re-examined. London, UK and New York, USA: Palgrave Macmillan.

Ashcroft, J., Childs, R., Myers, A. and Schluter, M. (2016). The Relational Lens: Understanding, Managing and Measuring Stakeholder Relationships. Cambridge: Cambridge University Press.

Attanasi, G., Casoria, F., Centorrino, S. and Urso, G. (2013). Cultural investment, local development and instantaneous social capital: A case study of a gathering festival in the South of Italy. Journal of Socio-Economics, 47, $228-47$.

Auten, G. and Rudney, G. (1990). The variability of individual charitable giving in the US. Voluntas, 1(2), 80-97.

Auten, G., Clotfelter, C. and Schmalbeck, R. (2000). Taxes and philanthropy among the wealthy. In J. Slemrod (ed.), Does Atlas Shrug? The Economic Consequences of Taxing the Rich (pp. 392-424). New York and Cambridge, MA, USA: Russell Sage and Harvard University Press.

Backer, J. (2000). Evaluating the Impact of Development Projects on Poverty: A Handbook for Practitioners. Washington, DC: World Bank.

Bardsley, N. (2000). Theoretical and Empirical Investigation of Nonselfish Behaviour: The Case of Contributions to Public Goods. PhD thesis. East Anglia.

Bardsley, N. (2008). Dictator game giving: Altruism or artefact? Experimental Economics, 11(2), 122-33.

Barnett, C., Cloke, P., Clarke, N. and Malpass, A. (2006). Research project (2003-2006): Governing the subjects and spaces of ethical consumption. Retrieved from http://www.open.ac.uk/socialsciences/research/spacesof-ethical-consumption.php.

Baron, D. (2010). Morally motivated self-regulation. American Economic Review, 100(4), 1299-329.

Bartolini, S. (2014). Buying alone: How the decreasing American happiness turned into the current economic crisis. Retrieved February 2015 from http://www.econ-pol.unisi.it/bartolini/papers/buyingalone.pdf.

Bartolini, S. and Sarracino, F. (2014). Happy for how long? How social capital and economic growth relate to happiness over time. Ecological Economics, 108, 242-56. 
Bartolini, S., Bilancini, E. and Pugno, M. (2013). Did the decline in social connections depress Americans' happiness? Social Indicators Research, 110(3), 1033-59.

Bartolini, S., Bonatti, L. and Sarracino, F. (2014). The great recession and the bulimia of U.S. consumers: Deep causes and possible ways out. Cambridge Journal of Economics, 38(5), 1015-42.

Bauer, T., Bredtmann, J. and Schmidt, C. (2012). Time vs. money: The supply of voluntary labor and charitable donations across Europe. RUHR Economic Papers No. 349.

Bebbington, A., Guggenheim, S., Olson, E. and Woolcock, M. (2004). Exploring social capital debates at the World Bank. Journal of Development Studies, 40(5), 33-64.

Becchetti, L., Corrado, L. and Conzo, P. (2013). Sociability, altruism and subjective well-being. CEIS Research Paper 270, Tor Vergata University, 11(5).

Bekkers, R. and Wiepking, P. (2007). Generosity and philanthropy: A literature review. Retrieved March 2014 from http://papers.ssrn.com/sol3/ papers.cfm?abstract_id=1015507.

Berger, P. and Luckmann, T. (1966). The Social Construction of Reality: A Treatise in the Sociology of Knowledge (1st edn). Garden City, NY: Doubleday.

BHPS Documentation (n.d.). Thesaurus. Retrieved September 2015 from https://www.iser.essex.ac.uk/bhps/documentation/volb/indexes/thesaur us.html.

Binzel, C. and Fehr, D. (2013). Giving and sorting among friends: Evidence from a lab-in-the-field experiment. IZA Discussion Paper No. 7516.

Birch, T. (1998). An analysis of Adam Smith's theory of charity and the problems of the poor. Eastern Economic Journal, 24(1), 25-41.

Bolton, G., Katok, E. and Zwick, R. (1998). Dictator game giving: Rules of fairness versus acts of kindness. International Journal of Game Theory, 27(2), 269-99.

Bowles, S. (2008). Policies designed for self-interested citizens may undermine "the moral sentiments": Evidence from economic experiments. Science, 320(5883), 1605-609.

Boyd, E. (2014). Exploring adaptive governance for managing tipping points. In T. O'Riordan and T. Lenton (eds), Addressing Tipping Points for a Precarious Future. British Academy Scholarship Online.

Boyd, E. and Folke, C. (2012). Adapting Institutions: Governance, Complexity, and Social-ecological Resilience. Cambridge, UK and New York, USA: Cambridge University Press.

Bradley, B. (1998). The importance of the civic sector. National Civic Review, 87(2), 161-6. 
Branas-Garza, P., Bucheli, M., Espinoza, M. and Garcia-Munoz, T. (2013). Moral cleansing and moral licencses: Experimental evidence. Economics and Philosophy, 29(2), 199-212.

Breeze, B. (2006). Robin Hood in reverse: Exploring the relationship between income and charitable giving. Voluntary Sector Working Paper No. 3, CCS, London School of Economics. Retrieved March 2014 from https://www.researchgate.net/publication/46133404.

Brewer, M. (1979). In-group bias in the minimal intergroup situation: Cognitive-motivational analysis. Psychological Bulletin, 86(2), 307-24.

Brewer, M. and Kramer, R. (1986). Choice behavior in social dilemmas: Effects of social identity, group-size, and decision framing. Journal of Personality and Social Psychology, 50(3), 543-9.

Brickman, P. and Campbell, D. (1971). Hedonic relativism and planning the good society. In M. Apley (ed.), Adaptation Level Theory: A Symposium (pp. 287-302). New York: Academic Press.

Brickman, P., Coates, D. and Janoff-Bulman, R. (1978). Lottery winners and accident victims: Is happiness relative? Journal of Personality and Social Psychology, 36(8), 917-27.

Bruni, L. (2000). Ego facing Alter: How economists have depicted human interactions. Annals of Public and Cooperative Economics, 71(2), 285-313.

Bruni, L. and Sugden, R. (2013). Reclaiming virtue ethics for economics. Journal of Economic Perspectives, 27(4), 141-63.

CAF (2010). World Giving Index 2010. Charities Aid Foundation. Retrieved March 2014 from https://www.cafonline.org/pdf/WorldGivingIndex280 92010Print.pdf.

CAF (2012). World Giving Index 2012. Charities Aid Foundation. Retrieved March 2014 from https://www.cafonline.org/PDF/WorldGivingIndex20 12WEB.pdf.

CAF (2014). World Giving Index 2014. Charities Aid Foundation. Retrieved March 2015 from https://www.cafonline.org/pdf/CAF_WGI2014_Repo rt_1555AWEBFinal.pdf.

CAF (2017). World Giving Index 2017. Charities Aid Foundation. Retrieved December 2017 from https://www.cafonline.org/about-us/publications.

Callinicos, A. (1983). The Revolutionary Ideas of Karl Marx. London: Bookmarks.

Carmichael, H. and MacLeod, W. (1997). Gift giving and the evolution of cooperation. International Economic Review, 38(3), 485-509.

Center on Philanthropy at Indiana University in the USA (2007). Patterns of household charitable giving by income group, 2005. Bloomington, IN: Indiana University.

CGAP (2013). Understanding Giving. Sharing Knowledge. CGAP Five 
Year Review, 2008-2013. London: Centre for Charitable Giving and Philanthropy, Cass Business School.

Chowdhury, S. and Jeon, J.Y. (2014). Impure altruism or inequality aversion?: An experimental investigation based on income effects. Journal of Public Economics, 118, 143-50.

Clark, A., Frijters, P. and Shields, M. (2008). Relative income, happiness, and utility: An explanation for the Easterlin paradox and other puzzles. Journal of Economic Literature, 46(1), 95-144.

Coleman, J. (1988). Social capital in the creation of human-capital. American Journal of Sociology, 94, S95-S120.

Cowley, E., McKenzie, T., Pharoah, C. and Smith, S. (2011). The New State of Donation: Three Decades of Household Giving to Charity, 1978-2008. CMPO/ CGAP Report.

Cox, J., Kerschbamer, R. and Neururer, D. (2014). What is trustworthiness and what drives it? Working Papers in Economics and Statistics, University of Innsbruck, eeecon, 2014-23.

Coyle, D. (2011). The Economics of Enough: How to Run the Economy as if the Future Matters. Princeton, NJ: Princeton University Press.

cpwlab (n.d.). Cambridge prosociality and wellbeing lab. Retrieved March 2014 from http://cpwlab.azurewebsites.net/Research.aspx

Crawford, J. and Henry, J. (2004). The positive and negative affect schedule (PANAS): Construct validity, measurement properties and normative data in a large non-clinical sample. British Journal of Clinical Psychology, 43, 245-65.

Daly, H. and Farley, J. (2004). Ecological Economics: Principles and Applications. Washington, DC: Island Press.

Dasgupta, P. (2009). A matter of trust: Social capital and economic development. Paper prepared for the Annual Bank Conference on Development Economics ( $A B C D E)$, June, Seoul.

Deckers, T., Falk, A., Kosse, F. and Szech, N. (2016). Homo moralis: Personal characteristics, institutions, and moral decision-making. Working Paper Series in Economics, Karlsruher Institut für Technologie (KIT), No. 85. Retrieved May 2016 from http://econstor.eu/bitstre am/10419/128641/1/848620968.pdf.

Degli Antoni, G. (2009). Intrinsic vs. extrinsic motivations to volunteer and social capital formation. Kyklos, 62(3), 359-70.

Della Giusta, M. (2003). Social capital and development: Issues of institutional design and trust in Mexican group-based microfinance. In F. Sforzi (ed.), The Institutions of Local Development (pp. 93-114). Aldershot: Ashgate.

Della Giusta, M. (2008). A theory of trust based systems of intermediation. Cambridge Journal of Economics, 32(1), 65-81. 
Della Vigna, S., List, J. and Malmendier, U. (2012). Testing for altruism and social pressure in charitable giving. Quarterly Journal of Economics, 127, 1-56.

Derin-Gure, P. and Uler, N. (2010). Charitable giving under inequality aversion. Economics Letters, 107(2), 208-10.

DeScioli, P. and Krishna, S. (2013). Giving to whom? Altruism in different types of relationships. Journal of Economic Psychology, 34, $218-28$.

Dessi, R. and Monin, B. (2012). Noblesse oblige? Moral identity and prosocial behavior in the face of selfishness. TSE Working Paper 12-347. Retrieved May 2015 from http://www.tse-fr.eu/sites/default/files/medias/ doc/wp/bee/wp_tse_347.pdf.

Dew, J. and Wilcox, W. (2013). Generosity and the maintenance of marital quality. Journal of Marriage and Family, 75(5), 1218-28.

Diener, E. and Biswas-Diener, R. (2008). Happiness: Unlocking the Mysteries of Psychological Wealth. Oxford: Wiley-Blackwell.

Dirks, W. (2005). Salt of the Earth. Bath: Eagle Publishing.

Douglas, M. (1990). Foreword. In M. Mauss, The Gift. London: Routledge.

Drösser, C. (2010). Geben macht glücklich (giving brings happiness). Die Zeit, 23 September, no. 39. Retrieved March 2014, from http://images. zeit.de/wissen/2010-09/s41-infografik-2.pdf.

Du Toit, A. (2004). 'Social exclusion' discourse and chronic poverty: A South African case study. Development and Change, 35(5), 987-1010.

Dunn, E., Aknin, L. and Norton, M. (2008). Spending money on others promotes happiness. Science, 319(5870), 1687-8.

Durlauf, S. and Fafchamps, M. (2004). Social capital. Wisconsin Madison - Social Systems Working Paper 12. Retrieved March 2014 from http:// www.ssc.wisc.edu/econ/archive/wp2004-12.pdf.

Easterlin, R. (1974). Does economic growth improve the human lot? Some empirical evidence. In P. David and M. Reder (eds), Nations and Households in Economic Growth (pp. 89-125). New York, USA and London, UK: Academic Press.

Ekman, P., Friesen, W. and Davidson, R. (1990). The Duchenne smile: Emotional expression and brain physiology. Journal of Personality and Social Psychology, 58(2), 342-53.

El-Said, H. and Harrigan, J. (2009). 'You reap what you plant': Social networks in the Arab world - the Hashemite Kingdom of Jordan. World Development, 37(7), 1235-49.

Ellul, J. (1984). Money and Power. Downers Grove, IL: InterVarsity Press. Elster, J. (2006). Altruistic behaviour and atruist motivations. In S-C. Kolm and J. Ythier (eds), Handbook on the Economics of Giving, Reciprocity and Altruism. Amsterdam, the Netherlands and London, UK: Elsevier. 
Engel, C. (2011). Dictator games: A meta study. Experimental Economics, 14(4), 583-610.

English, C. and Ray, J. (2011). Worldwide, personal wellbeing related to civic engagement: Religious adults also more likely to be civically engaged. Gallup. Retrieved March 2014, from http://www.gallup.com/ poll/145811/Worldwide-Personal-Wellbeing-Related-Civic-Engage ment.aspx.

Falk, A., Becker, A., Dohmen, T., Enke, B., Huffman, D. and Sunde, U. (2016). The nature and predictive power of preferences: Global evidence. Human Capital and Economic Opportunity Global Working Group Working Paper Series 2014-004. Retrieved May 2016 from http://humcap.uchi cago.edu/RePEc/hka/wpaper/Falk_Becker_etal_2016_nature-predictivepower.pdf.

Fehr, E. and Schmidt, K. (1999). A theory of fairness, competition, and cooperation. Quarterly Journal of Economics, 114(3), 817-68.

Fehr, E. and Schmidt, K. (2006). The economics of fairness, reciprocity and altruism: Experimental evidence and new theories. In S-C. Kolm and J. Ythier (eds), Handbook on the Economics of Giving, Reciprocity and Altruism. Amsterdam, the Netherlands and London, UK: Elsevier.

Fershtman, C., Gneezy, U. and List, J. (2009). Inequity, Selfishness, and Social Norms. Retrieved March 2014 from http://www.tau.ac.il/ fersht/ Papers/Inequity, $\% 20$ Selfishness $\% 20$ and $\% 20$ Social $\% 20$ Norms.pdf.

Fiske, A. (1992). The four elementary forms of sociality: Framework for a unified theory of social relations. Psychological Review, 99(4), 689-723.

Fong, C., Bowles, S. and Gintis, H. (2006). Stong reciprocity and the welfare state. In S-C. Kolm and J.M. Ythier (eds), Handbook on the Economics of Giving, Reciprocity and Altruism. Amsterdam, the Netherlands and London, UK: Elsevier.

Frank, R. (1985). Choosing the Right Pond: Human Behavior and the Quest for Status. New York, USA and Oxford, UK: Oxford University Press.

Frey, B. and Oberholzer-Gee, F. (1997). The cost of price incentives: An empirical analysis of motivation crowding-out. American Economic Review, 87(4), 746-55.

Frey, B. and Stutzer, A. (2002). What can economists learn from happiness research? Journal of Economic Literature, 40(2), 402-35.

Frumkin, P. (2002). On Being Non-profit: A Conceptual and Policy Primer. Cambridge, MA: Harvard University Press.

Giacomo, A. and Grimalda, G. (2012). The value of real voluntary associations. EconomEtica Working Paper 37. Retrieved March 2014 from http://econometica.it/wp/wp37.pdf. 
Giddens, A. (1984). The Constitution of Society: Outline of the Theory of Structuration. Cambridge: Polity.

Gore, A. (2007). An Inconvenient Truth: The Crisis of Global Warming (rev. edn). New York: Viking.

Granovetter, M. (1973). The strength of weak ties. American Journal of Sociology, 78(6), 1360-80.

Grant, E. (2001). Social capital and community strategies: Neighbourhood development in Guatemala City. Development and Change, 32(5), 975-97.

Grootaert, C. and Van Bastelaer, T. (2002). The Role of Social Capital in Development: An Empirical Assessment. Cambridge: Cambridge University Press.

Grugerty, M. and Kremer, M. (2002). The impact of development assistance on social capital: Evidence from Kenya. In C. Grootaert and T. van Bastelaer (eds), The Role of Social Capital in Development: An Empirical Assessment (pp. 213-33). Cambridge: Cambridge University Press.

Gui, B. (1996). On "relational goods": Strategic implications of investment in relationships. International Journal of Social Economics, 23(10/11), $260-78$.

Gui, B. and Sugden, R. (2010). Economics and Social Interaction: Accounting for Interpersonal Relations. Cambridge: Cambridge University Press.

Guiso, L., Sapienza, P. and Zingales, L. (2011). Civic capital as the missing link. In J. Benhabib, A. Bisin and M. Jackson (eds), Social Economics, Vol. $1 A$ (pp. 417-80). Amsterdam: Elsevier.

Halpern, D. (2005). Social Capital. Oxford: Polity Press.

Handy, C. and Handy, E. (2007). The New Philanthropists: The New Generosity. London: William Heinemann.

Harvard Kennedy School (n.d.). About social capital. Retrieved April 2015 from http://www.hks.harvard.edu/programs/saguaro/about-social-capi tal.

Helson, H. (1964). Adaptation-Level Theory: An Experimental and Systematic Approach to Behavior. New York: Harper \& Row.

Henrich, J., Boyd, R., Bowles, S., Camerer, C., Fehr, E. and Gintis, H. (2004). Foundations of Human Sociality: Economic Experiments and Ethnographic Evidence from Fifteen Small-Scale Societies. New York: Oxford University Press.

Hess, J., Fannin, A. and Pollom, L. (2007). Creating closeness: Discerning and measuring strategies for fostering closer relationships. Personal Relationships, 14(1), 25-44.

Hirsch, F. (1976). Social Limits to Growth. Cambridge, MA: Harvard University Press.

HM Treasury (2011). The Magenta Book: Guidence for Evaluation. HM 
Treasury. Retrieved March 2014 from https://www.gov.uk/govern ment/uploads/system/uploads/attachment_data/file/220542/magenta_ book_combined.pdf.

Hoffman, E., McCabe, K. and Smith, V. (1996). Social distance and otherregarding behavior in dictator games. American Economic Review, 86(3), 653-60.

Holland, J., Silva, A. and Mace, R. (2012). Lost letter measure of variation in altruistic behaviour in 20 neighbourhoods. PLoS ONE, 7(8), e43294.

Holloway, S., Tucker, L. and Hornstein, H. (1977). Effects of social and non-social information on interpersonal-behavior of males - news makes news. Journal of Personality and Social Psychology, 35(7), 514-22.

Hornstein, H., Lakind, E., Frankel, G. and Manne, S. (1975). Effects of knowledge about remote social events on prosocial behavior, social conception, and mood. Journal of Personality and Social Psychology, 32(6), $1038-46$.

Huppert, F. (2014). The state of well-being science: Concepts, measures, interventions and policies. In F. Huppert and C. Cooper (eds), Interventions and Policies to Enhance Well-being (pp. 1-50). Oxford: Wiley-Blackwell.

Inglehart, R., Foa, R., Peterson, C. and Welzel, C. (2008). Development, freedom, and rising happiness: A global perspective (1981-2007). Perspectives on Psychological Science, 3(4), 264-85.

Ipsos MORI and TNS-BMRB (2011).2010-11 Citizenship Survey Technical Report. Retrieved March 2014 from http://webarchive.nationalarchives. gov.uk/20120919132719/http://www.communities.gov.uk/communities/ research/citizenshipsurvey/technicalinformation/.

Jackson, T. (2009). Prosperity without Growth? The Transition to a Sustainable Economy. Sustainable Development Commission. Retrieved March 2014 from http://www.sd-commission.org.uk/publications.php?id=915.

James, H. (2015). Generalized morality, institutions and economic growth, and the intermediating role of generalized trust. Kyklos, 68(2), 165-96.

Johns Hopkins Global Civil Society Index (n.d.). Comparative Nonprofit Sector Project. Retrieved June 2015 from http://ccss.jhu.edu/ research-projects/comparative-nonprofit-sector-project/.

Kanbur, R. (2010). What determines poverty reduction? In D. Hulme, I. Matin and K. Moore (eds), What Works for the Poorest?: Poverty Reduction Programmes for the World's Extreme Poor. Rugby: Practical Action Publishing.

Kawachi, I., Subramanian, S. and Kim, D. (2008). Social Capital and Health. New York: Springer.

Keser, C. and Van Winden, F. (2000). Conditional cooperation and voluntary contributions to public goods. Scandinavian Journal of Economics, 102(1), 23-39. 
Khanna, J., Posnett, J. and Sandler, T. (1995). Charity donations in the UK: New evidence based on panel-data. Journal of Public Economics, 56(2), 257-72.

Knack, S. and Keefer, P. (1997). Does social capital have an economic payoff? A cross-country investigation. Quarterly Journal of Economics, 112(4), 1251-88.

Kolm, S-C. (2006). Reciprocity: Its scope, rationales and consequences. In S-C. Kolm and J. Ythier (eds), Handbook on the Economics of Giving, Reciprocity and Altruism. Amsterdam, the Netherlands and London, UK: Elsevier.

Kolm, S-C. (2010). The logic of good social relations. In B. Gui and R. Sugden (eds), Economics and Social Interaction: Accounting for Interpersonal Relations. Cambridge: Cambridge University Press.

Kolm, S-C. and Ythier, J. (2006). Handbook on the Economics of Giving, Reciprocity and Altruism. Amsterdam, the Netherlands and London, UK: Elsevier.

Konow, J. (2010). Mixed feelings: Theories of and evidence on giving. Journal of Public Economics, 94(3-4), 279-97.

Korenok, O., Millner, E. and Razzolini, L. (2012). Are dictators averse to inequality? Journal of Economic Behavior \& Organization, 82(2-3), 543-7.

Kosse, F., Deckers, T., Schildberg-Hörisch, H. and Falk, A. (2016). The Formation of Prosociality: Causal Evidence on the Role of Social Environment. IZA DP No. 9861. Retrieved May 2016 from http://ftp. iza.org/dp9861.pdf.

Kramer, R. (1991). Intergroup relations and organizational dilemmas: The role of categorization processes. In L. Cummings and B. Staw (eds), Research in Organizational Behaviour (pp. 191-228). Greenwich: CT: JAI Press.

Krishna, A. (2002). Active Social Capital: Tracing the Roots of Development and Democracy. New York, USA and Chichester, UK: Columbia University Press.

Krishna, A. and Uphoff, N. (2002). Mapping and measuring social captial through assessment of collective action to conserve and develop watersheds in Rajasthan, India. In C. Grootaert and T. Van Bastelaer (eds), The Role of Social Capital in Development: An Empirical Assessment (pp. 85-124). Cambridge: Cambridge University Press.

Lalonde, R. and Silverman, R. (1994). Behavioral preferences in response to social injustice - the effects of group permeability and social identity salience. Journal of Personality and Social Psychology, 66(1), 78-85.

Lane, R. (2001). The Loss of Happiness in Market Democracies. New Haven, CT: Yale Univeristy Press. 
Latusek, D. and Cook, K. (2012). Trust in transitions. Kyklos, 65(4), $512-25$.

Layard, R. (2005). Happiness: Lessons from a New Science. London: Allen Lane.

Levy-Garboua, L., Meidinger, C. and Rapoport, B. (2006). The formation of social preferences: Some lessons from psychology and biology. In S-C. Kolm and J. Ythier (eds), Handbook on the Economics of Giving, Reciprocity and Altruism. Amsterdam, the Netherlands and London, UK: Elsevier.

Lindsey, R. (2012). Exploring local hotspots and deserts: Investigating the localdistribution of charitableresources. CGAP Working Paper. Retrieved March 2014 from http://www.cgap.org.uk/uploads/Working\%20Papers/ CGAP $\% 20$ WP $\% 20$ hotspots $\% 20$ and $\% 20$ deserts $\% 20$ RLindsey.pdf.

List, J. (2011). The market for charitable giving. Journal of Economic Perspectives, 25(2), 157-80.

Lloyd, T. (2004). Why Rich People Give. London: Association of Charitable Foundations.

Madson, L. (1997). Models of the self: Self-construals and gender. Psychological Bulletin, 122(1), 5-37.

Malmendier, U., te Velde, V. and Weber, R. (2014). Rethinking reciprocity. Annual Review of Economics, 6(6), 849-74.

Mauss, M. (1954). The Gift. London: Cohen and West.

Mayo, J. and Tinsley, C. (2009). Warm glow and charitable giving: Why the wealthy do not give more to charity. Journal of Economic Psychology, 30, 490-99.

Mochon, D., Norton, M. and Ariely, D. (2008). Getting off the hedonic treadmill, one step at a time: The impact of regular religious practice and exercise on well-being. Journal of Economic Psychology, 29(5), 632-42.

Mosse, D. (2006). Collective action, common property, and social capital in South India: An anthropological commentary. Economic Development and Cultural Change, 54(3), 695-724.

Myers, D. and Diener, E. (1997). The pursuit of happiness. Scientific American, 7, 40-43.

NEF(2004). A Wellbeing Manifestofor a Flourishing Society. New Economics Foundation. Retrieved February 2015 from http://www.neweconomics. org/publications/entry/a-well-being-manifesto-for-a-flourishing-society.

North, D.(1990). Institutions, Institutional Changeand Economic Performance. Cambridge: Cambridge University Press.

OECD (2001). The Well-being of Nations: The Role of Human and Social Capital. Paris: OECD. Retrieved March 2014 from http://www.oecd. org/dataoecd/36/40/33703702.pdf. 
OECD (2011). Perspectives on Global Development 2012: Social Cohesion in a Shifting World. Paris: OECD. Retrieved June 2015 from http://www. oecd.org/site/devpgd2012/49067954.pdf.

OECDi-library (2011). Society at a Glance. Relationship Between Public Social Spending and Inequality. Retrieved September 2014 from http://www.oe cd-ilibrary.org/sites/soc_glance-2011-en/06/05/index.html?contentType= \&itemId=/zcontent/chapter/soc_glance-2011-20-en\&containerItemId=/ content/serial/19991290\&accessItemIds=/content/book/soc_glance-2011en\&mimeType=text $/ \mathrm{html}$.

Office for National Statistics (2013). Ward Level Mid-Year Population Estimates (experimental), Mid-2011 (Census Based) Statistical Bulletin. Retrieved October 2015 from http://www.ons.gov.uk/ons/dcp 171778_311891.pdf.

Ogawa, K., Takemoto, T., Takahashi, H. and Suzuki, A. (2012). Income earning opportunity and work performance affect donating behavior: Evidence from dictator game experiments. Journal of Socio-Economics, 41(6), 816-26.

Okten, C. and Weisbrod, B.A. (2000). Determinants of donations in private nonprofit markets. Journal of Public Economics, 75(2), 255-72.

Oosterbeek, H., Sloof, R. and Van de Kuilen, G. (2004). Cultural differences in ultimatum game experiments: Evidence from a meta-analysis. Experimental Economics, 7(2), 171-88.

Orford, S., Dorling, D., Mitchell, R., Shaw, M. and Smith, G. (2002). Life and death of the people of London: A historical GIS of Charles Booth's inquiry. Health \& Place, 8(1), 25-35.

Ortiz, I. and Cummins, M. (2011). Global inequality: Beyond the bottom billion. UNICEF. Retrieved March 2014 from http://www.unicef.org/ socialpolicy/files/Global_Inequality.pdf.

Ostrom, E. (1996). Crossing the great divide: Coproduction, synergy, and development. World Development, 24(6), 1073-87.

Ostrom, E. (2000). Social capital: A fad or a fundamental concept? In P. Dasgupta and I. Serageldin (eds), Social Capital: A Multifaceted Perspective (pp. 172-214). Washington, DC: World Bank.

Oswald, A. and Wu, S. (2010). Objective confirmation of subjective measures of human well-being: Evidence from the USA. Science, 327(5965), 576-9.

Paik, A. (2011). Social networks, recruitment and volunteering: Are social capital effects conditional on recruitment? Nonprofit and Voluntary Sector Quarterly, 40, 476-96.

Payne, A. and Smith, J. (2015). Does income inequality increase charitable giving? Canadian Journal of Economics, 48(2), 793-818. 
Pemberton, J. (1995). Charitable behaviour. Discussion Papers in Economics, University of Reading, Department of Economics, Series A, VII(302).

Piekalkiewicz, M. (2016). Money, social capital and materialism: Evidence from happiness data. Quaderni del Dipartimento di Economia Politica e Statistica, No. 731. Retrieved April 2016 from http://d.repec.org/n?u=R ePEc:zbw:esprep:130185\&r=soc.

Polanyi, K. (1944). The Great Transformation. New York, USA and Toronto, Canada: Farrar \& Rinehart.

Portes, A. and Landolt, P. (2000). Social capital: Promise and pitfalls of its role in development. Journal of Latin American Studies, 32, 529-47.

Putnam, R. (2000). Bowling Alone: The Collapse and Revival of American Community. New York, USA and London, UK: Simon \& Schuster.

Putnam, R. (2015). Our Kids: The American Dream in Crisis. New York, USA and London, UK: Simon \& Schuster.

Putnam, R., Leonardi, R. and Nanetti, R. (1993). Making Democracy Work: Civic Traditions in Modern Italy. Princeton, NJ, USA and Chichester, UK: Princeton University Press.

Putterman, L. (2006). Altruism and cooperative production. In S-C. Kolm and J. Ythier (eds), Handbook on the Economics of Giving, Reciprocity and Altruism. Amsterdam, the Netherlands and London, UK: Elsevier.

Quibria, M. (2003). The Puzzle of Social Capital: A Critical Review. Manila: Asian Development Bank, Economics and Research Department.

Rankin, K. (2002). Social capital, microfinance, and the politics of development. Feminist Economics, 8(1), 1-24.

Relational Analytics (n.d.). Measure, manage and leverage organizational relationships. Retrieved September 2015 from http://www.relationalanalytics.com/.

Ross, L. and Ward, A. (1996). Naive realism in everyday life: Implications for social conflict and misunderstanding. In E. Reed, E. Turiel and T. Brown (eds), Values and Knowledge. Mahwah, NJ: Erlbaum.

Rotemberg, J. (2006). Altruism, reciprocity and cooperation in the workplace. In S-C. Kolm and J. Ythier (eds), Handbook on the Economics of Giving, Reciprocity and Altruism. Amsterdam, the Netherlands and London, UK: Elsevier.

Rothstein, B. and Uslaner, E. (2005). All for all: Equality, corruption, and social trust. World Politics, 58(1), 41-72.

Ryff, C. (1989). Happiness is everything, or is it: Explorations on the meaning of psychological well-being. Journal of Personality and Social Psychology, 57(6), 1069-81.

Sacco, P., Vanin, P. and Zamagni, S. (2006). The economics of human 
relationships. In S-C. Kolm and J. Ythier (eds), Handbook on the Economics of Giving, Reciprocity and Altruism. Amsterdam, the Netherlands and London, UK: Elsevier.

Sampson, R., Raudenbush, S. and Earls, F. (1997). Neighborhoods and violent crime: A multilevel study of collective efficacy. Science, 277(5328), 918-24.

Sanders, M. and Smith, S. (2016). Can simple prompts increase bequest giving? Field evidence from a legal call centre. Journal of Economic Behavior \& Organization, 125, 179-91.

Sargeant, A. and Shang, J. (2010). Fundraising Principles and Practice. San Francisco, CA, USA: Jossey-Bass.

Scharf, K. and Smith, S. (2016). Relational altruism and giving in social groups. Journal of Public Economics, 141, 1-10.

Schechter, L. (2007). Theft, gift-giving, and trustworthiness: Honesty is its own reward in rural Paraguay. American Economic Review, 97(5), $1560-82$.

Schiff, J. (1985). Does government spending crowd out charitable contributions? National Tax Journal, 38(4), 535-46.

Schneider, F. and Weber, R. (2013). Long-term commitment and cooperation. Working Paper 130. University of Zurich, Department of Economics.

Schokkaert, E. (2006). The empirical analysis of transfer motives. In S-C. Kolm and J. Ythier (eds), Handbook on the Economics of Giving, Reciprocity and Altruism. Amsterdam, the Netherlands and London, UK: Elsevier.

Science of Generosity (n.d.). The Science of Generosity Initiative, University of Notre Dame. Retrieved March 2014 from http://generosityresearch. nd.edu/

Sen, A. (2005). Human rights and capabilities. Journal of Human Development, 6(2), 151-66.

Sen, A. (2009). The Idea of Justice. London: Allen Lane.

Sen, B. (1987). NGO self-evaluation: Issues of concern. World Development, 15, Supplement 1, 161-7.

Serra, R. (2011). The promises of a new social capital agenda. Journal of Development Studies, 47(8), 1109-27.

Silvey, R. and Elmhirst, R.(2003). Engenderingsocialcapital: Women workers and rural-urban networks in Indonesia's crisis. World Development, 31(5), $865-79$.

Smith, D. (1994). Determinants of voluntary association participation and volunteering: A literature review. Nonprofit and Voluntary Sector Quarterly, 23(3), 243-63.

Sobel, J. (2002). Can we trust social capital? Journal of Economic Literature, 40(1), 139-54. 
Solnick, S. and Hemenway, D. (1998). Is more always better? A survey on positional concerns. Journal of Economic Behavior and Organization, 37(3), 373-83.

Steptoe, A., Wardle, J. and Marmot, M. (2005). Positive affect and healthrelated neuroendocrine, cardiovascular, and inflammatory processes. Proceedings of the National Academy of Sciences of the United States of America, 102(18), 6508-12.

Stiglitz, J., Sen, A. and Fitoussi, J-P. (2009). Report by the commission on the measurement of economic performance and social progress. Retrieved April 2015 from http://www.stiglitz-sen-fitoussi.fr/documents/ rapport_anglais.pdf.

Stutzer, A. (2004). The role of income aspirations in individual happiness. Journal of Economic Behavior \& Organization, 54(1), 89-109.

Sugden, R. (1984). Reciprocity - the supply of public-goods through voluntary contributions. Economic Journal, 94(376), 772-87.

Suh, E., Diener, E. and Fujita, F. (1996). Events and subjective well-being: Only recent events matter. Journal of Personality and Social Psychology, 70(5), 1091-102.

Svendsen, G. (2014). Trust. Gylling: Aarhus University Press.

Thaler, R. and Sunstein, C. (2008). Nudge: Improving Decisions about Health, Wealth, and Happiness. New Haven, CT and London, UK: Yale University Press.

Tillema, T., Dijst, M. and Schwanen, T. (2010). Face-to-face and electronic communications in maintaining social networks: The influence of geographical and relational distance and of information content. New Media \& Society, 12(6), 965-83.

Uphoff, N.(1986). Local Institutional Development: An Analytical Sourcebook with Cases. West Hartford, CT: Kumarian Press.

Uslaner, E. (2000). Producing and consuming trust. Political Science Quarterly, 115(4), 569-90.

Vajja, A. and White, H. (2008). Can the World Bank build social capital? The experience of social funds in Malawi and Zambia. Journal of Development Studies, 44(8), 1145-68.

Van Lange, P. (1999). The pursuit of joint outcomes and equality in outcomes: An integrative model of social value orientation. Journal of Personality and Social Psychology, 77(2), 337-49.

Van Lange, P. and Joireman, J. (2008). How we can promote behavior that serves all of us in the future. Social Issues and Policy Review, 2(1), $127-57$.

Van Praag, B. and Frijters, P. (1999). The measurement of welfare and well-being: The Leyden approach. In E. Diener, D. Kahneman and 
N. Schwarz (eds), Well-being: The Foundations of Hedonic Psychology. New York: Russell Sage Foundation.

Von Kotzebue, A. (2010). Private contributions to collective concerns: Modelling donor behaviour. Cambridge Journal of Economics, 34(2), 367-87.

Waring, M. (1989). If Women Counted: A New Feminist Economics. London: Macmillan.

Watson, D., Clark, L. and Tellegen, A. (1988). Development and validation of brief measures of positive and negative affect - the PANAS scales. Journal of Personality and Social Psychology, 54(6), 1063-70.

Wei, Q. and Zhang, Y. (2014). Inequality aversion and altruistic donation behavior-based on dictator games. In 2014 4th International Conference on Applied Social Science (ICASS 2014), Pt 2, 52, 144-150.

Wicksteed, P. (1933). The Common Sense of Political Economy. London: Routledge.

Wilkinson, R. and Pickett, K. (2009). The Spirit Level: Why More Equal Societies Almost Always do Better. London, UK and New York, USA: Allen Lane.

Wit, A. and Wilke, H. (1992). The effect of social categorization on cooperation in three types of social dilemmas. Journal of Economic Psychology, 13(1), 135-51.

Woolcock, M. and Narayan, D. (2000). Social capital: Implications for development theory, research, and policy. World Bank Research Observer, 15(2), 225-49.

World Bank(2000). New paths to socialdevelopment: community and global networks in action, Washington, DC: World Bank. Retrieved March 2014 from https://siteresources.worldbank.org/INTRANETSOCIAL DEVELOPMENT/Resources/NewPathsSocialSummit.pdf.

Yamamura, E. (2012a). Charitable giving under inequality aversion and social capital. MPRA. Retrieved April 2015 from http://mpra.ub.unimuenchen.de/37975/.

Yamamura, E. (2012b). Norm for redistribution, social capital, and perceived tax burden: comparison between high- and low-income households. MPRA. Retrieved from http://mpra.ub.uni-muenchen.de/39434/.

Yamamura, E. (2012c). Trust in government and its effect on preferencs for income redistribution and perceived tax burden. MPRA. Retrieved March 2014 from http://mpra.ub.uni-muenchen.de/39833/.

Ythier, J. (2006). The economic theory of gift-giving: Perfect substitutability of transfers and redistribution of wealth. In S-C. Kolm and J. Ythier (eds), Handbook on the Economics of Giving, Reciprocity and Altruism. Amsterdam, the Netherlands and London, UK: Elsevier. 
Zischka, L. (2013). Valuing social capital by the resources people allocate to one another. Journal of International Development, 25(5), 609-25.

Zischka, L. (2018). The link between prosocial (giving) behaviours and social cohesion. Revista Internacional de Sociologia, 76(1), Retrieved May 2018 from https://doi.org/10.3989/ris.2018.76.1.15.125.

Zischka, L. in collaboration with Berkshire Community Foundation (2014). Philanthropy in Berkshire and its contribution to community wellbeing. Retrieved December 2014 from http://www.berkshirecommunity foundation.org.uk/uploads/files/philanthropy-report.pdf.

\section{Key Surveys}

British Household Panel Survey: University of Essex. Institute of Social and Economic Research (ISER), funded by the Economic and Social Research Council (ESRC). British Household Panel Survey: Waves 6-18, 1996-2008. Supplied by the UK Data Archive.

Citizenship Survey: Ipsos MORI in partnership with TNS-BMRB, commissioned by the Department for Communities and Local Government (DCLG). Citizenship Survey (2008-2011). Supplied by the UK Data Archive.

Understanding Society: University of Essex. Institute for Social and Economic Research (ISER). Survey delivery by National Centre for Social Research and TNS-BMRB. Funded by the Economic and Social Research Council (ESRC). Understanding Society: Waves 1-3, 20092012. Supplied by the UK Data Archive. 